\title{
Molybdate treatment and sulfate starvation decrease ATP and DNA levels in Ferroplasma acidarmanus
}

\author{
DAVID J. BAUMLER, ${ }^{1}$ KAI-FOONG HUNG ${ }^{2}$ KWANG CHEOL JEONG ${ }^{2}$ and CHARLES \\ W. KASPAR ${ }^{1-3}$ \\ ${ }^{1}$ Cellular and Molecular Biology, University of Wisconsin, Madison, Wisconsin, USA \\ ${ }^{2}$ Department of Bacteriology, University of Wisconsin, Madison, Wisconsin, USA \\ ${ }^{3}$ Corresponding author (cwkaspar@wisc.edu)
}

Received June 16, 2008; accepted October 13, 2008; published online October 27, 2008

\begin{abstract}
Summary Sulfate is a primary source of sulfur for most microbes and in some prokaryotes it is used an electron acceptor. The acidophile Ferroplasma acidarmanus (strain fer1) requires a minimum of $150 \mathrm{mM}$ of a sulfate-containing salt for growth. Sulfate is assimilated by F. acidarmanus into proteins and reduced to form the volatile organic sulfur compounds methanethiol and dimethyldisulfide. In the absence of sulfate, cell death occurs by an unknown mechanism. In this study, cell viability and genomic DNA and ATP contents of $F$. acidarmanus were monitored in response to the absence of sulfate or the presence of sulfate and the sulfate analog molybdate $\left(\mathrm{MoO}_{4}^{2-}\right)$. Cellular DNA and ATP contents were monitored as markers of cell viability. The absence of sulfate led to a decrease in viable cell numbers of greater than $7 \log _{10}$ within 5 days, a $>99 \%$ reduction in genomic DNA within 3 days, and a $>60 \%$ decrease in ATP within $6 \mathrm{~h}$. Likewise, cells incubated with $\mathrm{MoO}_{4}^{2-}$ lost viability (decreased by $>2 \log _{10}$ in 5 days), extractable genomic DNA (reduction of $>60 \%$ in 2 days), and ATP (reduction of $>70 \%$ in 2 hours). These results demonstrate that sulfate deprivation or the presence of molybdate have similar impacts on cell viability and essential biomolecules. Sulfate was coupled to cellular ATP content and maintenance of DNA integrity in F. acidarmanus, a finding that may be applicable to other acidophiles that are typically found in sulfate-rich biotopes.
\end{abstract}

Keywords: Ferroplasma, acidophile, sulfate, sulfur, archaea.

\section{Introduction}

Archaea of the Crenarchaeota branch are polyextremophiles that are both acidophilic and thermophilic and include: Sulfolobus spp., Acidianus spp., Metallosphaera spp., Sulfurococcus yellowstonensis, Sulfurisphaera ohwakuensis, Stygiolobus azoricus, and Acidilobus aceticus (Hallberg and Johnson 2001). The acidophilic Euryarchaeota belong to the order Thermoplasmatales and comprise four genera: the recently described Thermogymnomonas acidicola (Itoh et al. 2007), Thermoplasma spp., Picrophilis spp. and Ferroplasma spp. This order has been the subject of some study, because three of the four genera have at least one isolate with a completed genome sequence (Ruepp et al. 2000, Futterer et al. 2004, Allen et al. 2007). Moreover, Picrophilus oshimae and Ferroplasma acidarmanus share the unique ability to grow at pH 0.0 (Schleper et al. 1995, Edwards et al. 2000).

Growth of prokaryotes at extremely low $\mathrm{pH}$ generally requires at least three characteristics: (1) a unique membrane composition; (2) homeostatic systems for maintenance of internal $\mathrm{pH}$; and (3) the ability to protect and repair essential cellular components. When grown in medium at $\mathrm{pH}_{\mathrm{ex}}$ of 1.0 , F. acidarmanus has a $\mathrm{pH}_{\mathrm{i}}$ of approximately 5.5 , thus representing one of the largest $\Delta \mathrm{pH}$ gradients for an acidophilic microorganism (Macalady et al. 2004). Yet, it is currently unknown how the internal $\mathrm{pH}$ of $F$. acidarmanus is maintained in an external environment that supports growth as low as $\mathrm{pH} 0.0$.

Ferroplasma acidarmanus grows optimally at a sulfate concentration of $350 \mathrm{mM}$ and constitutively produces the volatile sulfur gas methanethiol (MT) through metabolism of methionine and cysteine, and through the reduction of sulfate via the assimilatory or dissimilatory pathway (Baumler et al. 2007). Despite the presence of amino acids and other sulfur-containing compounds in the yeast extract present in growth media for $F$. acidarmanus, sulfate supplementation is necessary to support growth and maintain viability. Dopson et al. (2007) reported that $F$. acidarmanus does not employ sulfate as an electron acceptor as evidenced by the absence of growth; however, the growth medium used in this study had a total sulfate concentration that was insufficient to support growth (150 $\mathrm{mM}$ to $1 \mathrm{M}$ sulfate is necessary) (Baumler et al. 2007). Moreover, the production of hydrogen sulfide by Ferroplasma thermophilum suggests that sulfate serves as an electron acceptor in anaerobic conditions in other Ferroplasma species (Zhou et al. 2008).

To begin to characterize the role of sulfate, viability measurements and ATP contents of F. acidarmanus were monitored during incubation in the absence of sulfate and in sulfate-containing medium with added molybdate $\left(\mathrm{MoO}_{4}^{2-}\right)$, a sulfate analog known to inhibit sulfate respiration (Taylor and 
Oremland 1979, Oremland and Capone 1988). Lower pH is known to accelerate DNA damage by depurination (Lindahl and Nyberg 1972); therefore, genomic DNA was monitored as a marker for cytoplasmic homeostasis and cellular viability. ATP cellular contents were also monitored to determine if sulfate was associated with the generation or maintenance of energy. Results from this study further emphasize the essential role of sulfate in $F$. acidarmanus and suggest that sulfate or sulfate reduction play a role in $\mathrm{pH}$ homeostasis or is coupled to ATP generation.

\section{Materials and methods}

\section{Bacterial strain and growth conditions.}

Ferroplasma acidarmanus strain fer1 was grown in a basal salts medium (NoS, Baumler et al. 2007) supplemented with the addition of $0.1 \%$ yeast extract (w/v) and $350 \mathrm{mM} \mathrm{Na}_{2} \mathrm{SO}_{4}$ (SNoS). Freshly prepared medium was inoculated as described (Macalady et al. 2004, Baumler et al. 2007). Growth studies were conducted with static incubation at $37^{\circ} \mathrm{C}$.

\section{Viability during sulfate starvation}

The survival of $F$. acidarmanus was monitored in basal NoS with either $350 \mathrm{mM} \mathrm{Na}_{2} \mathrm{SO}_{4}$ or $100 \mathrm{mM} \mathrm{NaCl}$ (to maintain osmotic conditions) and incubated at $37{ }^{\circ} \mathrm{C}$. Cells from a 7-day culture (log-phase) were harvested, washed, and used as inoculum (Baumler et al. 2007). Samples were periodically removed and viable cell counts determined by Most Probable Number (MPN) method (Baumler et al. 2005).

\section{DNA content of cells incubated without sulfate or with molybdate}

Cells from $200 \mathrm{ml}$ of a 14-day culture grown in SNoS medium were pelleted by centrifugation $(10,000 \mathrm{~g}, 10 \mathrm{~min})$. Cells were washed twice with NoS growth medium and then resuspended in $100 \mathrm{ml}$ of acidified yeast extract $(0.1 \%)$ adjusted to $\mathrm{pH} 1.0$ with either $\mathrm{H}_{2} \mathrm{SO}_{4}$ or $\mathrm{HCl}$, and incubated at $37{ }^{\circ} \mathrm{C}$. In experiments involving molybdate addition, cells were resuspended in $0.1 \%$ yeast extract $\left(\mathrm{pH} 1.0\right.$, adjusted with $\left.\mathrm{H}_{2} \mathrm{SO}_{4}\right)$ containing either 0,5 , or $20 \mathrm{mM}$ of $\mathrm{Na}_{2} \mathrm{MoO}_{4} \cdot 2 \mathrm{H}_{2} \mathrm{O}$ (Sigma) and incubated at $37^{\circ} \mathrm{C}$. Samples were removed at the designated times to determine the MPN of viable cells and extract genomic DNA (1.5 $\mathrm{ml}$ of cell suspension). The DNeasy Tissue kit (Qiagen Inc., Valencia, CA) was used, including the incubation step with ribonuclease A (Sigma, St. Louis, MO), following the manufacturer's instructions. The DNA was quantified and checked for purity based on $\mathrm{A}_{260}$ and $\mathrm{A}_{280}$ measurements with a DU-800 Beckman spectrophotometer (Beckman Coulter Inc., Fullerton, CA).

\section{ATP contents incubated without sulfate or with molybdate}

Similar to the experimental design used to monitor cellular DNA contents, $F$. acidarmanus was grown in SNoS medium and cells from $200 \mathrm{ml}$ of a 14-day culture was pelleted by centrifugation $(10,000 \mathrm{~g}, 10 \mathrm{~min})$ and washed twice. Cells were then resuspended in $200 \mathrm{ml}$ of acidified yeast extract
$(0.1 \%)$ adjusted to $\mathrm{pH} 2.0$ with $\mathrm{HCl}$ or $\mathrm{H}_{2} \mathrm{SO}_{4}\left(5 \mathrm{mM} \mathrm{SO}_{4}^{2-}\right.$ from $\left.\mathrm{H}_{2} \mathrm{SO}_{4}\right) \cdot \mathrm{Na}_{2} \mathrm{MoO}_{4} \cdot 2 \mathrm{H}_{2} \mathrm{O}$ was added $(20 \mathrm{mM})$ to the medium acidified with $\mathrm{H}_{2} \mathrm{SO}_{4}$. The cell suspensions were incubated at $37{ }^{\circ} \mathrm{C}$, and $30-\mathrm{ml}$ samples removed periodically and the cells pelleted by centrifugation. The cell pellet was resuspended in $1.0 \mathrm{ml}$ of $\mathrm{NoS}$ adjusted to $\mathrm{pH} 4.5$ with $\mathrm{H}_{2} \mathrm{SO}_{4}$. The ATP was determined by the BacTiter-Glo Microbial Cell Viability Assay (Promega, Madison, WI) following the manufacturer's instructions and luminescence determined with a Synergy HT Multi-mode Microplate reader (Biotek, Vermont, USA). The quantity of cellular ATP was determined using a standard curve prepared with purified ATP (Sigma).

\section{Statistical analysis}

The data reported are the mean values from three independent trials. The data were analyzed for statistical differences by the $t$-test.

\section{Results and discussion}

\section{Viability in the absence of sulfate}

Ferroplasma acidarmanus loses viability when incubated in the absence of sulfate (Baumler et al. 2007). This study examined the relationship between cell viability and the presence or absence of sulfate. The number of viable cells started to decline during the initial 6 hours of incubation in the absence of sulfate, and decreased by $>2 \log _{10}$ after 1 day and $>5 \log _{10}$ after five days of incubation (Figure 1). These results demonstrate that, in that the absence of sulfate, there was a precipitous drop in cell viability. It is unlikely that cell death was caused by the presence of $200 \mathrm{mM} \mathrm{Cl}^{-}$ion because

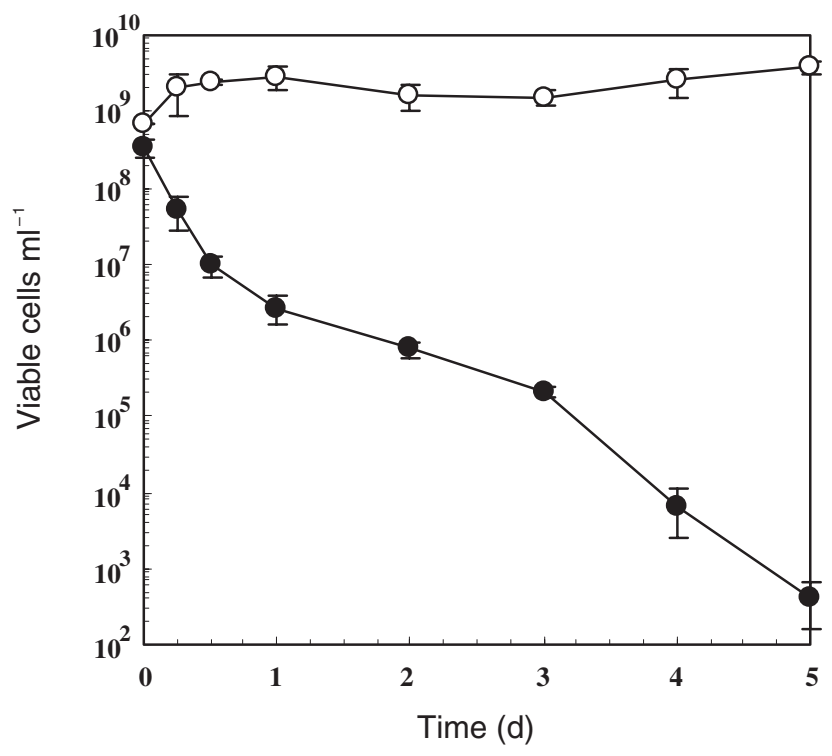

Figure 1. Survival in the absence of sulfate. Survival of $F$. acidarmanus in NoS medium (pH $1.0 \mathrm{HCl}, 0.1 \%$ yeast extract) with no sulfate (O) or with $350 \mathrm{mM} \mathrm{NaSO}(\bigcirc)$. Mean values from three independent trials are reported with error bars representing the standard error of the mean. 
F. acidarmanus grows chemolithotrophically in the presence of $100 \mathrm{mM} \mathrm{FeCl}_{2}$ (Baumler et al. 2005).

\section{DNA content of cells incubated in sulfate-free medium}

Ferroplasma acidarmanus requires $>150 \mathrm{mM} \mathrm{SO}_{4}^{2-}$ for growth and a minimum of $1 \mathrm{mM} \mathrm{SO}_{4}^{2-}$ for survival (Baumler et al. 2007). In the absence of sulfate, cells remained intact when viewed microscopically (data not shown) implying that the loss of viability was not due to osmotic shock or membrane disruption. Furthermore, cells pelleted by centrifugation from cultures incubated with and without sulfate appeared to be similar in size (data not shown), which indicates that cell lysis did not occur. Because nucleic acid is essential to life, DNA can be used as an indicator of cell viability and homeostasis. Therefore, the quantity of genomic DNA was monitored in cells suspended in acidified yeast extract $(0.1 \%)$ adjusted to pH 1.0 with either $5 \mathrm{M} \mathrm{H}_{2} \mathrm{SO}_{4}$ or $5 \mathrm{M} \mathrm{HCl}$. When $\mathrm{H}_{2} \mathrm{SO}_{4}$ $\left(50 \mathrm{mM} \mathrm{SO}_{4}^{2-}\right.$ ) was used as acidulate, both the number of viable cells and the amount of DNA content remained constant throughout 7 days of incubation (Figure 2). The absence of sulfate $\left(\mathrm{pH} 1.0 \mathrm{HCl}\left(100 \mathrm{mM} \mathrm{Cl}^{-}\right)\right)$resulted in a decrease of $>7 \log _{10}$ viable cells $\mathrm{ml}^{-1}$ while extractable DNA declined $>2$ $\log _{10} \mu \mathrm{g}$ DNA ml${ }^{-1}$.

DNA is subject to depurination at low pH. Deinococcus radiodurans is a bacterium that is resistant to ionizing radiation, ultraviolet light, and desiccation, but sensitive to low $\mathrm{pH}$ because of acid-accelerated depurination of DNA (Imamura et al. 1999). The depurination of DNA is well characterized and results in the removal of purine bases by hydrolysis of the $\mathrm{N}$-glycosyl bond forming an apurinic (AP) site in DNA. The rate constant of depurination is influenced by both $\mathrm{pH}$ and temperature, and increases at lower $\mathrm{pH}$ and higher tempera-

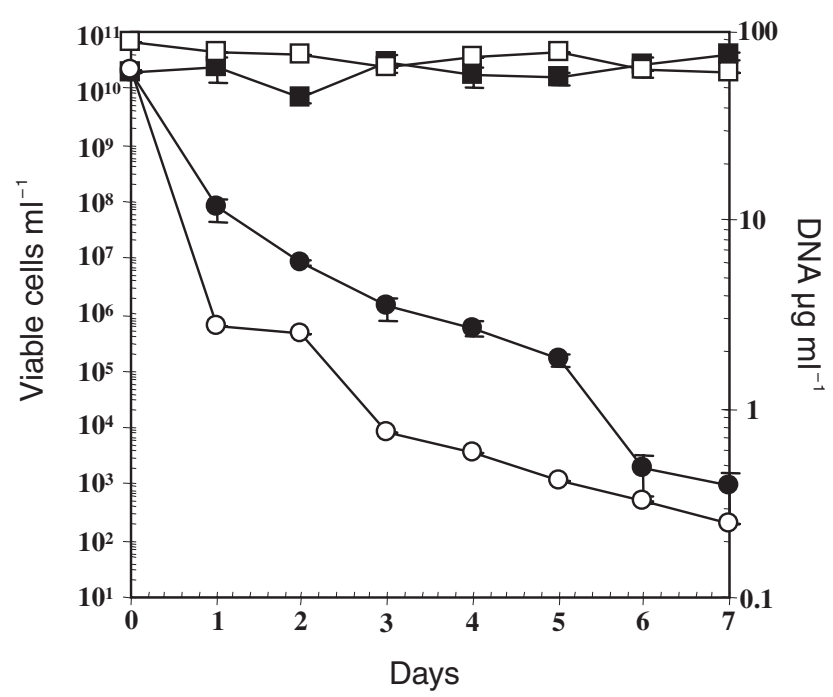

Figure 2. Quantity of extractable DNA in response to the absence of sulfate. Number of viable cells $(\boldsymbol{\square}, \mathbf{0})$ and DNA concentrations $(\square, \bigcirc)$ from $F$. acidarmanus in $0.1 \%$ yeast extract acidified to $\mathrm{pH} 1.0$ with either $\mathrm{H}_{2} \mathrm{SO}_{4}(\boldsymbol{\square}, \square)$ or $\mathrm{HCl}(\boldsymbol{\bullet}, \bigcirc)$. Values represent the means from three independent trials. Error bars represent the standard error of the mean. tures (Lindahl and Nyberg 1972). Once an AP site is formed, a group of enzymes, including glycosylases, AP endonucleases, DNA polymerase and DNA ligase, carry out base-excision repair. A survey of the completed genome of $F$. acidarmanus identified three candidate ORFs for AP endonucleases that could contribute to DNA repair. One of the first proteins purified and characterized from $F$. acidarmanus was AGTendoV, which is involved in DNA repair with both $O^{6}$-alkylguanine-DNA alkyltransferase and endonuclease $\mathrm{V}$ activities (Kanugula et al. 2005). Because of the importance of DNA integrity, all cells contain DNA repair enzymes. These enzymes may be particularly important to extremophiles, such as acidophiles and thermophiles that must be adept at repairing damage that can result from the conditions of their environment, especially when cellular homeostatic systems are not operating effectively. For example, a drop in cytoplasmic $\mathrm{pH}$ can overwhelm DNA-repair systems employing enzymes that function optimally at or near neutral $\mathrm{pH}$, resulting in DNA damage. The results from our study demonstrated that the quantity of DNA in F. acidarmanus decreased and was probably degraded into small fragments because the column used for DNA purification had a MW cut-off of $\geq 100 \mathrm{bp}$. One possible scenario to explain the decrease in quantity of DNA is that sulfate starvation caused a drop in cytoplasmic $\mathrm{pH}$ that resulted in acid-accelerated depurination of DNA and consequently decreased amounts of extractable DNA. It is unknown how sulfate might contribute to $\mathrm{pH}$ homeostasis.

\section{DNA content of cells incubated with molybdate}

Specific inhibitors of sulfate reduction have been used in studies of microbial ecology to study competition for hydrogen between sulfate-reducers and methanogens (Oremland 1976). These inhibitors are group VI oxyanions, namely $\mathrm{MoO}_{4}^{2-}$, $\mathrm{CrO}_{4}^{2-}, \mathrm{WO}_{4}^{2-}$, and $\mathrm{SeO}_{4}^{2-}$, and all function through structural mimickery of $\mathrm{SO}_{4}^{2-}$. The inhibitors are imported through sulfate transporters and used as substrates in the first enzymatic step of sulfate reduction, the activation of sulfate to adenosine 5 -phosphosulfate (APS) by ATP sulfurylase. Once activated, the oxyanions bind irreversibly to APS reductase and inhibit further sulfate reduction (Oremland and Capone 1988). $\mathrm{MoO}_{4}^{2-}$ has been found to inhibit sulfate reduction in various Desulfovibrio spp. and also in the sulfate-reducing archaeon Archaeoglobus profundus (Tor et al. 2003). These competitive inhibitors are used at concentrations up to $20 \mathrm{mM}$ (Oremland and Capone 1988).

The DNA content of cells incubated in $0.1 \%$ yeast extract acidified with $\mathrm{H}_{2} \mathrm{SO}_{4}$ (adds $50 \mathrm{mM} \mathrm{SO}_{4}^{2-}$ ) plus $\mathrm{MoO}_{4}^{2-}$ at 0,5 , or $20 \mathrm{mM}$ was monitored. The DNA content decreased significantly $(P<0.005)$ in cells incubated for 3 days with $5 \mathrm{mM}$ or $20 \mathrm{mM} \mathrm{MoO}_{4}^{2-}$ compared with control cells in which the DNA content remained constant (Figure 3). In the absence of sulfate, DNA concentrations and cell viability were more strongly affected than in the molybdate treatment, which may be a result of incomplete inhibition or competition of molybdate in the presence of $50 \mathrm{mM} \mathrm{SO}_{4}^{2-}$ or both. These results show that incubation of cells in the presence of $\mathrm{MoO}_{4}^{2-}$ or in the absence of sulfate has a similar effect on the quantity of DNA in cells. 


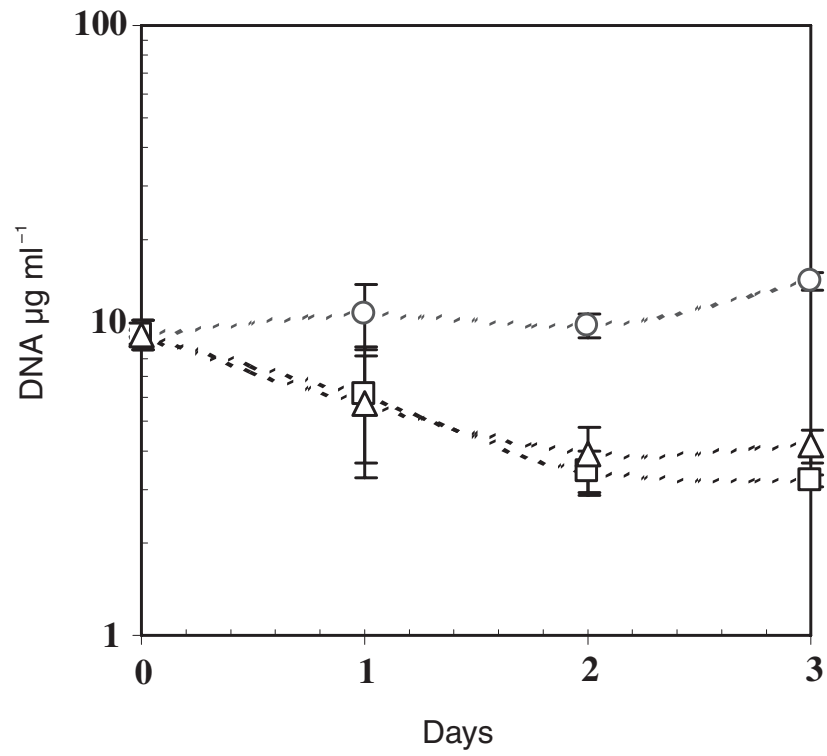

Figure 3. Effect of $\mathrm{MoO}_{4}^{2-}$ on the quantity of extractable DNA. Genomic DNA concentrations from $F$. acidarmanus cells suspended in $0.1 \%$ yeast extract acidified to $\mathrm{pH} 1.0$ with $\mathrm{H}_{2} \mathrm{SO}_{4}(\mathrm{O})$ and with the addition of $5 \mathrm{mM}(\square)$ or $20 \mathrm{mM}(\triangle) \mathrm{MoO}_{4}^{2-}$. All values represent means of three trials. Error bars represent the standard error of the mean.

\section{Influence of sulfate deprivation or molybdate on cellular ATP content}

To further assess the detrimental effect of sulfate starvation on F. acidarmanus viability, cellular ATP contents and viability were monitored in $0.1 \%$ yeast extract adjusted to $\mathrm{pH} 2.0$ with either $5 \mathrm{M} \mathrm{H}_{2} \mathrm{SO}_{4}$ or $5 \mathrm{M} \mathrm{HCl}$. In the absence of sulfate, cellu-

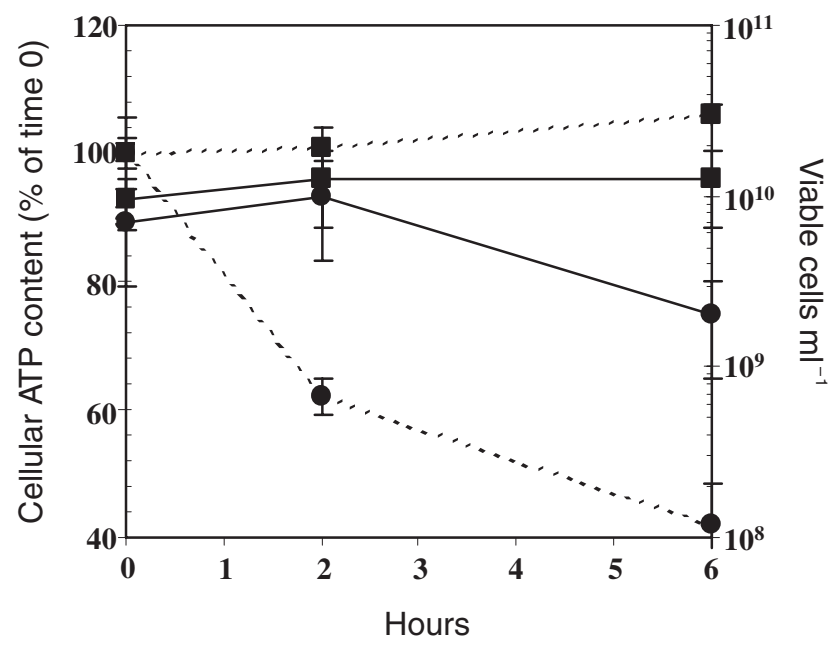

Figure 4. Cellular ATP content in the absence of sulfate. Number of viable cells $(\mathbf{\square}, \mathbf{\bullet})$ and ATP contents $(\mathbf{\square - -}, \mathbf{-}-)$ from $F$. acidarmanus in $0.1 \%$ yeast extract acidified to $\mathrm{pH} 2.0$ with either $\mathrm{H}_{2} \mathrm{SO}_{4}(\boldsymbol{\square})$ or $\mathrm{HCl}(-)$. All values represent the means of three independent trials each with two replicates. Error bars represent the standard error of the mean.

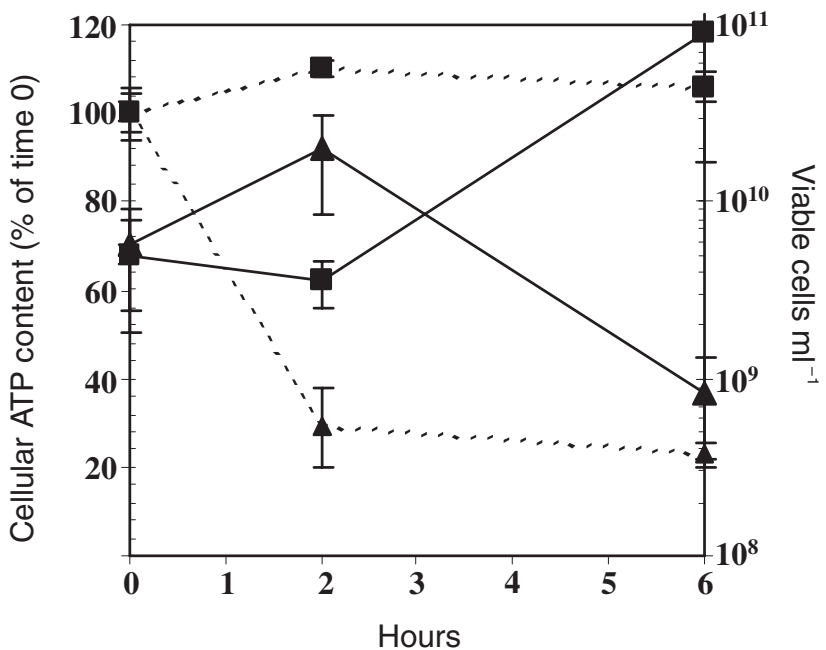

Figure 5. Cellular ATP content following molybdate addition. Num-

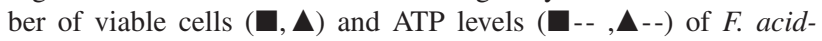
armanus in $0.1 \%$ yeast extract and acidified to $\mathrm{pH} 2.0$ with $\mathrm{H}_{2} \mathrm{SO}_{4}$

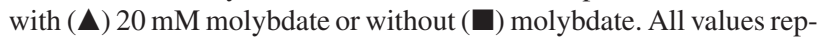
resent the means of three independent trials each with two replicates. Error bars represent the standard error of the mean.

lar ATP contents decreased to $42 \%$ of the time zero quantity $(1.98 \pm 0.04 \mu \mathrm{M})$ after $6 \mathrm{~h}$ of incubation in sulfate-free conditions, whereas, in control cells, the ATP content remained unchanged (Figure 4). Similar to the results with sulfate starvation, ATP contents decreased in cells $(0.73 \pm 0.03 \mu \mathrm{M})$ incubated with molybdate to $<23 \%$ of the time zero quantity. Again, the ATP contents of control cells remained constant ( $106 \%$ of the time zero amounts $(2.58 \pm 0.15 \mu \mathrm{M})$ ) (Figure 5). The difference in the time zero quantities of cellular ATP between control and molybdate-treated cells was most likely due to $\mathrm{MoO}_{4}^{2-}$ exposure that occurred during the resuspension and centrifugation steps of the ATP assay. Thus, the loss of ATP began immediately or within minutes of $\mathrm{MoO}_{4}^{2-}$ addition.

Most microorganisms use sulfate as a sulfur source (assimilative sulfate reduction) to produce cysteine and methionine and other essential organic sulfur compounds,

Table 1. Effect of molybdate on cellular ATP content.

\begin{tabular}{lc} 
Organism & ATP (\% of control) \\
\hline Ferroplasma acidarmanus ${ }^{1}$ & 29 \\
Escherichia coli ATCC 14948 (aerobic) $)^{2,3}$ & 107 \\
Escherichia coli ATCC 14948 (anaerobic) $)^{2,3}$ & 348 \\
Desulfovibrio sp. (marine isolate) $)^{2,4}$ & 45 \\
Desulfovibrio desulfuricans ATCC $7757^{2.4}$ & 21 \\
\hline${ }^{1}$ Cell suspensions from cultures exposed to $20 \mathrm{mM} \mathrm{MoO}_{4}^{2-}$ for $2 \mathrm{~h}$ at \\
$37^{\circ} \mathrm{C}$. \\
2 Taylor and Oremland (1979). \\
${ }^{3}$ Cell suspensions from cultures exposed to $20 \mathrm{mM} \mathrm{MoO}_{4}^{2-}$ for \\
30 min at $30{ }^{\circ} \mathrm{C}$. \\
${ }^{4}$ Cell suspensions from cultures exposed to $10 \mathrm{mM} \mathrm{MoO}_{4}^{2-}$ for \\
30 min at $30{ }^{\circ} \mathrm{C}$.
\end{tabular}


whereas sulfate-reducing bacteria use sulfate as an electron acceptor in an energy-generating process (dissimilative sulfate reduction). Sulfate must be activated with ATP before it can be used in either pathway. The addition of $\mathrm{MoO}_{4}^{2-}$ to cultures of sulfate-reducing bacteria depletes cells of ATP. The effect of molybdate on ATP contents of sulfate-reducing bacteria are compared with the values determined in this study for F. acidarmanus (Table 1). Both the absence of sulfate and the addition of the sulfate-reduction inhibitor, molybdate, resulted in a rapid depletion of cellular ATP and linked the cellular ATP content with sulfate respiration, flux or an energy-requiring secondary response (i.e., ATP-dependent DNA repair enzymes). The addition of molybdate, even in the presence of sulfate, resulted in a lower ATP content (23\% of time zero value) than the absence of sulfate ( $42 \%$ of time zero value). The greater reduction in cellular ATP with molybdate addition may be due to the use of ATP to activate the sulfate analog, which then binds irreversibly to the second enzyme in sulfate reduction (APS reductase) and prevents further reduction and potential energy generation. However, this would imply that F. acidarmanus is capable of dissimilative sulfate reduction, which is plausible considering the detection of hydrogen sulfide production by F. thermophilum (Zhou et al. 2008), but additional studies are needed. The absence of sulfate resulted in a greater reduction in cell viability and cellular DNA content than molybdate addition.

\section{Conclusion}

Results of this study demonstrated that $F$. acidarmanus has an absolute requirement for sulfate and loses viability in the absence of sulfate with concomitant decreases in cellular ATP and DNA contents. Likewise, the addition of the sulfate analog, molybdate, resulted in similar effects on viability and cellular ATP and DNA contents. These results suggest F. acidarmanus is capable of traditional dissimilative sulfate reduction or employs sulfur compounds in unique roles for cellular homeostasis. As most acidophilic prokaryotes are found in sulfate-rich biotopes, studies are in progress to ascertain if other acidophiles have a congruous requirement for sulfate.

\section{Acknowledgments}

This work was supported by the Michael and Winona Foster Wisconsin Distinguished Graduate Fellowship (DJB) and in part by NSF-LexEn Grant MCB-9978205 and the University of Wisconsin-Madison, College of Agricultural and Life Science.

\section{References}

Allen, A.A., G.W. Tyson, R.J. Whitaker, J.C. Detter, P.M. Richardson and J.F. Banfield. 2007. Genome dynamics in a natural archaeal population. Proc. Natl. Acad. Sci. USA 104:1883-1888.

Baumler, D.J., K.-F. Hung, K.C. Jeong and C.W. Kaspar. 2007. Production of methanethiol and volatile sulfur compounds by the archaeon "Ferroplasma acidarmanus". Extremophiles 11: 841-851
Baumler, D.J., K.C. Jeong, B.G. Fox, J.F. Banfield and C.W. Kaspar. 2005. Sulfate requirement for heterotrophic growth of "Ferroplasma acidarmanus" strain fer1. Res. Microbiol. 156: 492-498.

Dopson, M., C. Baker-Austin and P. Bond. 2007. Towards determining details of anaerobic growth coupled to ferric iron reduction by the acidophilic archaeon 'Ferroplasma acidarmanus' Fer1. Extremophiles 11:159-168.

Edwards, K.J., P.L. Bond, T.M. Gihring and J.F. Banfield. 2000. An archaeal iron-oxidizing extreme acidophile important in acid mine drainage. Science 287:1796-1799.

Futterer, O., A. Angelov, H. Liesegang, G. Gottschalk, C. Schleper, B. Schepers, C. Dock, G. Antranikian and W. Liebl. 2004. Genome sequence of Picrophilus torridus and its implications for life around pH 0. Proc. Natl. Acad. Sci. USA 101:9091-9096.

Hallberg, K.B. and D.B. Johnson. 2001. Biodiversity of acidophilic prokaryotes. Adv. Appl. Microbiol. 49:37-84.

Imamura, M., K. Harada, S. Sawada, K. Akagi and T. Ohnishi. 1999. Damage to DNA purified from the radioresistant prokaryote, Deinococcus radiodurans, by acid heating. Int. J. Mol. Med. 3: 391-395.

Itoh, T., N. Yoshikawa and T. Takashina. 2007. Thermogymnomonas acidicola gen. nov., sp. nov., a novel thermoacidophilic, cell wall-less archaeon in the order Thermoplasmatales, isolated from a solfataric soil in Hakone, Japan. Int. J. Syst. Evol. Microbiol. 57:2557-2561.

Kanugula, S., G.T. Pauly, R.C. Moschel and A.E. Pegg. 2005. A bifunctional DNA repair protein from Ferroplasma acidarmanus exhibits $O^{6}$-alkylguanine-DNA alkyltransferase and endonuclease V activities. Proc. Natl. Acad. Sci. USA. 102:3617-3622.

Lindahl, T. and B. Nyberg. 1972. Rate determination of native deoxyribonucleic acid. Biochemisty 11:3610-3618.

Macalady, J.L., M.M. Vestling, D.J. Baumler, N. Boekelheide, C.W. Kaspar and J.F. Banfield. 2004. Tetraether-linked membrane monolayers in Ferroplasma spp: a key to survival in acid. Extremophiles 8:411-419.

Oremland, R.S. and D.G. Capone. 1988. Use of specific inhibitors in biogeochemistry and microbial ecology. Adv. Microbiol. Ecol. 10:285-383.

Oremland, R.S. 1976. Studies on the methane cycle in tropical marine sediments. PhD thesis, University of Miami, Miami, Florida, 108 p.

Ruepp, A., W. Graml, M.L. Santos-Martinez, K.K. Koretke, C. Volker, H.W. Mewes, D. Frishman, S. Stocker, A.N. Lupas and W. Baumeister. 2000. The genome sequence of the thermoacidophilic scavenger Thermoplasma acidophilum. Nature 407:466-467.

Schleper, C., G. Puehler, I. Holz, A. Gambacorta, D. Janekovic, U. Santarius, H.-P. Klenk and W. Zillig. 1995. Picrophilus gen. Nov., Fam. nov.: a novel aerobic, heterotrophic, thermoacidophilic genus and family comprising Archaea capable of growth around pH 0. J. Bacteriol. 177:7050-7059.

Taylor, B.F. and R.S. Oremland. 1979. Depletion of adenosine triphosphate in Desulfovibrio by oxyanions of group VI elements. Curr. Microbiol. 3:101-103.

Tor, J.M., J.P. Amend and D.R. Lovley. 2003. Metabolism of organic compounds in anaerobic, hydrothermal sulphate-reducing marine sediments. Environ. Microbiol. 5:583-591.

Zhou, H., R. Zhang, P. Hu, W. Zeng, Y. Xie, C. Wu and G. Qiu. 2008. Isolation and characterization of Ferroplasma thermophilum sp. nov., a novel extremely acidophilic, moderately thermophilic archaeon and its role in bioleaching of chalcopyrite. J. Appl. Microbiol. 105:591-601. 

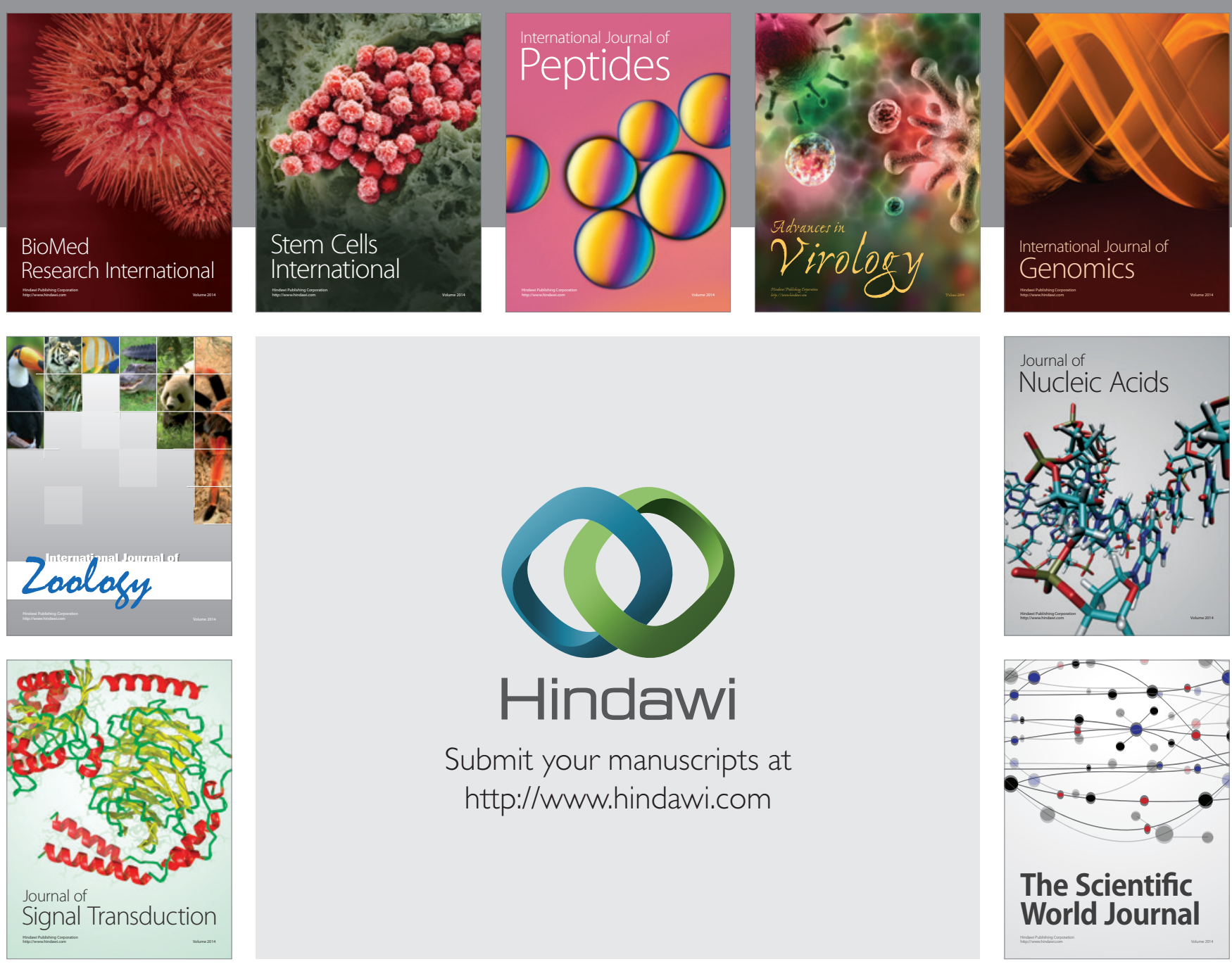

Submit your manuscripts at

http://www.hindawi.com
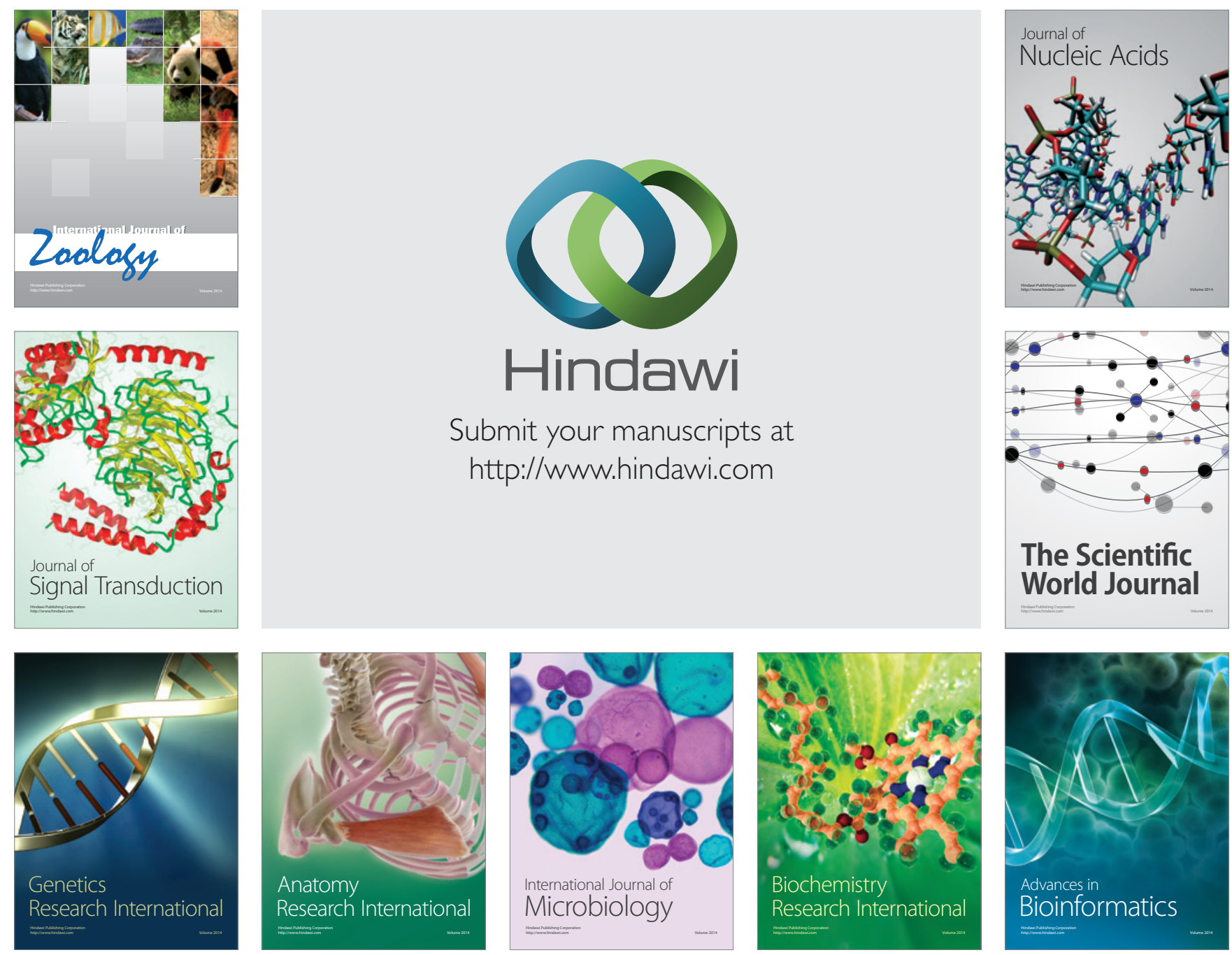

The Scientific World Journal
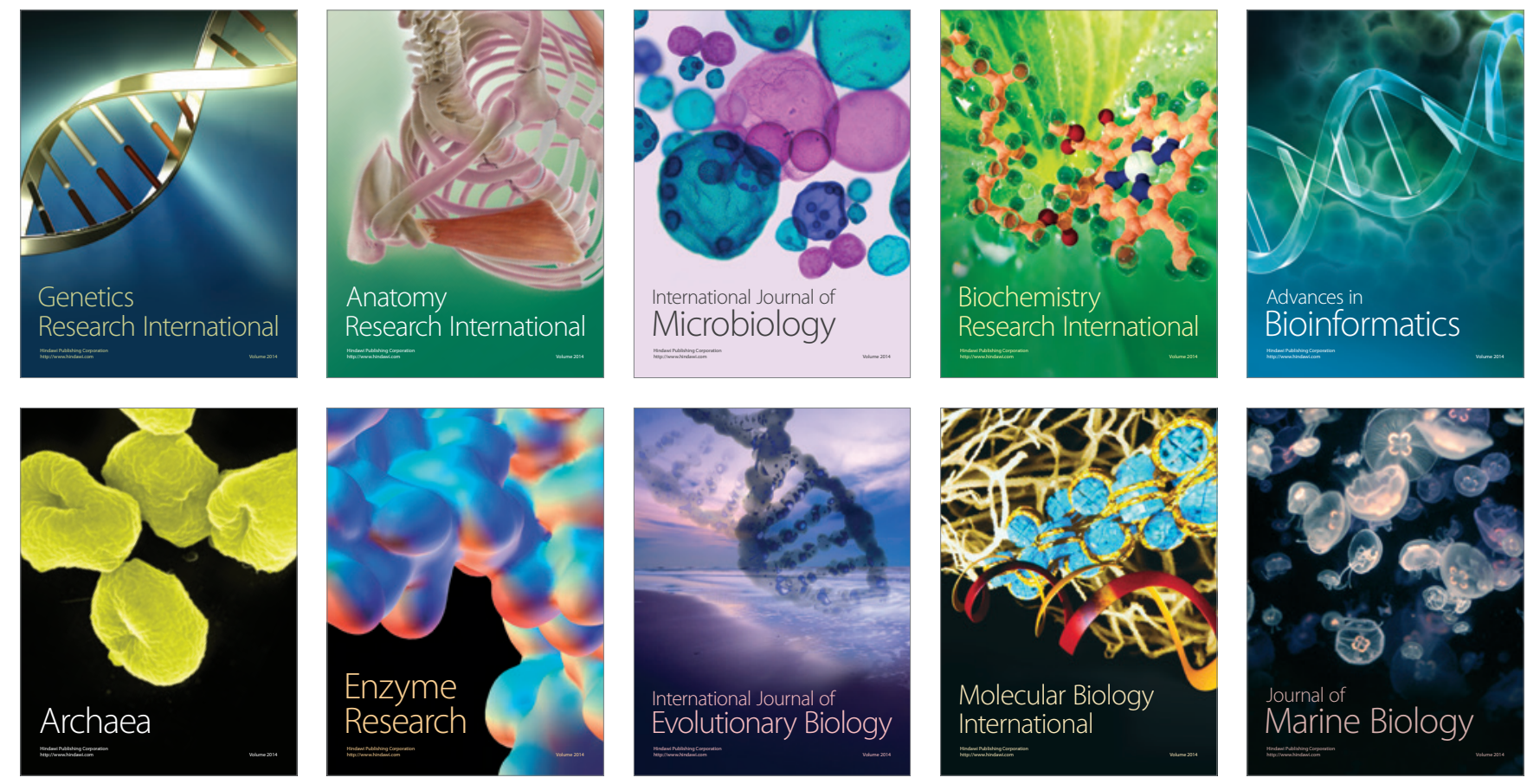